\title{
CONTENTS VOLUME 5
}

Editorial

The contribution of experimental information retrieval to librarianship and information studies P.G.B. ENSER

Does education for special librarianship need to be "special education"? WILLIAM FISHER

Library and information science education in Morocco: observations on a recent visit to the

"Ecole des Sciences de I'Information" and the "Centre National de Documentation" in Rabat B. LOUGHRIDGE

OST-Online Search Tutor (Software Section)

C.J. ARMSTRONG and J.A. LARGE

Book Reviews

Book Notices

News

Translations of Abstracts

Calendar of Events

Editorial

KEVIN MCGARRY and P. KAEGBEIN

Looking towards the future: an overview PETER HAVARD-WILLIAMS

What the consumer looks for

F.W. RATCLIFFE

Needs and gaps in the training of information specialists

H.-R. SIMON

From library studies to information science

WILLIAM J. MARTIN

Curriculum theory and library and information science

Education and training in the information fields - the curriculum and research STEPHEN A. ROBERTS

Recent German educational trends in the information and documentation field: integrating subject fields into information science programmes

The "BID" model test of the Polytechnic of Hanover: principles, structures, solutions and problems of new studies in the field of librarianship, information and documentation GUNTER BOCK 
Educating the public librarian, educating the special librarian - is there a common future? WINFRIED GÖDERT

The Stuttgart reform concept

F. BIENERT

Colloquium on the harmonization of education and training programmes for library, information and archival personnel

RUSSELL BOWDEN

Calendar of Events

Editorial

Education and training for librarianship and information work: annual bibliography, 1986 ALAN J. CLARK

Manpower development needs as depicted by the human resources survey of scientific and technical libraries in India

INDER VIR MALHAN

Improving the quality of library and information science education in countries other than

Canada and the United States: an investigation concerning regulations and guidelines

PATRICIA F. BEILKE and VALERIE A. THOMPSON

The use of CARDBOX in library and information studies education (Software Section)

R.J. HARTLEY

Nichemanship for the nineties (Short Communication)

BLAISE CRONIN

Conference Reports

Book Reviews

Book Notices

News

Translations of Abstracts

Calendar of Events

Author Index Volume 5 